\title{
Taxonomic transfer of Gongrosira fluminensis Fritsch (Chaetophorales, Chlorophyceae) to Lithotrichon Darienko et Pröschold (Ulvales, Ulvophyceae) based on morphological observation and phylogenetic analyses
}

\author{
Benwen LiU ${ }^{1,2}$, Qinghua WANG ${ }^{1,2}$, Shuyin $\mathrm{Li}^{1,2}$, Jiao FANG ${ }^{1,2}$, Guoxiang LiU ${ }^{1 *}$ \& \\ Zhengyu $\mathrm{Hu}^{3}$
}

\author{
${ }^{1}$ Key Laboratory of Algal Biology, Institute of Hydrobiology, Chinese Academy of Sciences, Wuhan 430072, PR \\ China;*Corresponding authore-mail:liugx@ihb.ac.cn \\ ${ }^{2}$ University of Chinese Academy of Sciences, Beijing 100039, PR China \\ ${ }^{3}$ State Key Laboratory of Freshwater Ecology and Biotechnology, Institute of Hydrobiology, Chinese Academy \\ of Sciences, Wuhan 430072, PR China
}

\begin{abstract}
One green algal specimen from China was identified as Gongrosira fluminensis FrITSCH, due to its unique morphology that pseudoparenchymal basal stratum with rounded or polygonal cells grew into dense little-branched upright threads that reached approximately the same height with specific akinete formation and germination and formed strong cushions without calcification. Examination of the ultrastructural characteristics of plasmodesmata and pyrenoid confirmed that Gongrosira fluminensis Fritsch should be excluded from the order Chaetophorales. The phylogenetic evidence based on DNA sequence data from the nucleus (18S rDNA, ITS rDNA) and chloroplast (tufA) sequences clearly revealed that the Gongrosira fluminensis Fritsch should be classified in the Ulvales (Ulvophyceae) as the new combination species of the genus Lithotrichon Darienko et Pröschold, instead of the Chaetophorales (Chlorophyceae). More specimens in conjunction with natural morphological investigation and molecular analyses are required to reevaluate the microfilamentous genus Gongrosira Kützing and reveal hidden diversities among the Ulvophyceae.
\end{abstract}

Key words: Chaetophorales, Gongrosira, Gongrosira fluminensis, ITS rDNA, tufA, Ulvophyceae, 18S rDNA

\section{INTRODUCTION}

The genus Gongrosira Kützing was established based on the species Gongrosira sclerococcus Kützing, one of the four species initially described by Kützing, among which only Gongrosira sclerococcus Kützing was currently recognized as belonging to the genus (KÜTZING 1843). This species had been described ten years earlier by KüTZING (1833) under the name Stereococcus viridis Kützing. The question of priority was considered by SILVA (1952) who decided to conserve Gongrosira Kützing against the earlier name and Gongrosira sclerococcus Kützing was the lectotype (TUPA 1974). Gongrosira Kützing occurred as very small, cushion-like growths on stones in rivers and creeks, and that the plants were heavily incrusted with calcium carbonate crystals (PRINTZ 1964).

The concept of the genus Gongrosira Kützing has developed largely from characters contributed by species subsequently assigned to this genus which has been allied with various Chaetophoralean algae (PrintZ 1964; Bourrelly 1972; Tupa 1974) including the Trentepohliaceae (FrITSCH 1935; SMITH 1950). Gongrosira fluminensis Kützing was initially described as a new species because of its pseudoparenchymal basal stratum with rounded or polygonal cells grew into dense little-branched upright threads that reached approximately the same height with specific akinete formation and germination and formed strong cushions without calcification (FriTSCH 1929). PRINTZ (1964) reported twenty species in the genus Gongrosira Kützing including Ctenocladus Borzi, A. many of which are poorly known and doubtful. Pleurothamnion papuasica Borzi, A. was taxonomically realigned within the genus Gongrosira Kützing (TUPA 1974). Characterized by the presence of a well-defined primary prostrate axis and secondary axes, Gongrosira pseudoprostrata Johnson, L.R. et John, D.M. as a new species was described (JoHNSON \& JoHN 1992). To date, there are 36 species names in the database of which 25 have been flagged as accepted taxonomically on the basis of the listed literature under the species name (GUIRY \& GUIRY 2018).

The taxonomic position of Gongrosira Kützing 
varies according to different phycologists and the taxonomic history of Gongrosira Kützing has included artificial alignments with groups based on its vegetative morphology. The genus Gongrosira Kützing has been placed in the Trentepohliaceae on the basis of vegetative morphological features including the presence of a branched thallus typified by a distinct prostrate and erect portion (SмIтH 1950) and certain specializations like the incrustation with carbonate seen in some representatives (Fritsch 1935). Watanabe et al. (1992) placed the Gongrosira papuasica (Borzi) Tupa, A. among the Chlorococcaceae. On the basis of branched growth forms, cytological features of the cell wall and pyrenoid, and the presence of ovoid zoospores with eyespots, PRINTZ (1964) placed the genus Gongrosira Kützing among the Chaetophorales followed by most of phycologists (HU \& WeI 2006; WeHr et al. 2015; GUIRY \& GUIRY 2018). Molecular data clearly showed that the genus Ctenocladus Borzi, A. is a member of Ulvophyceae (LIU et al. 2016). Recent studies have shown that there may be cryptic lineages in microfilamentous algae with similar morphology in Ulvophyceae such as Hazenia Bold, H.C. and Pseudendoclonium Wille (ŠKKALOUD et al. 2013), and morphology may not be a good indicator of phylogenetic relatedness such as in Ulvella Crouan, P. \& Crouan H. (O'Kelly et al. 2004; NiELSEN et al. 2013). Many Gongrosira taxa have been described and different taxonomic status have been assigned, but none of them have been investigated using modern molecular techniques. Gongrosira fluminensis Fritsch, one common species of the genus Gongrosira Kützing (CAMBRA SÁnCHEZ et al. 1998; JoHn 2002; Hu \& WeI 2006; JoHN et al. 2011; MAULOOD et al. 2013; WEHR et al. 2015; TÄUSCHER 2016) had been collected and cultured successfully in our lab. Taking all these facts into account, the present study is to determine the phylogenetic relationship of Gongrosira fluminensis Fritsch based on morphological observation and phylogenetic analyses.

\section{Materials ANd Methods}

The voucher specimen described herein was deposited in the Freshwater Algae Culture Collection at the Institute of Hydrobiology (FACHB collection), Chinese Academy of Sciences, Wuhan, China. Detailed information were listed in Table 1.
Each sample was preserved in 4\% formalin for the morphological study. Microphotographs were taken with an Olympus BX53 light microscope (Olympus Corp., Tokyo, Japan) using the differential interference contrast method. The photographs were taken under an oil immersion objective lens. Natural samples were isolated using an Olympus SZX7 microscope (Olympus Corp., Tokyo, Japan) and rinsed with double-distilled $\mathrm{H}_{2} \mathrm{O}$. The algae were grown in culture dishes on sterilized BBM medium (BISCHOFF \& BOLD 1963) solidified with 1.2\% agar under the photon fluence rate of $15-35 \mu \mathrm{mol} \cdot \mathrm{m}^{-2} \cdot \mathrm{s}^{-1}$ in a $14: 10 \mathrm{~h}$ light:dark cycle at $20^{\circ} \mathrm{C}$. Cells undergoing exponential growth were collected for Genomic DNA extracted and transmission electron microscopy (TEM). The algal samples were fixed for $2 \mathrm{~h}$ at $5{ }^{\circ} \mathrm{C}$ in $2 \%$ glutaraldehyde and $0.05 \mathrm{M}$ phosphate buffer. They were post-fixed for $2 \mathrm{~h}$ at $5{ }^{\circ} \mathrm{C}$ in $1 \%$ osmium tetroxide and $0.05 \mathrm{M}$ phosphate buffer and then overnight at $5{ }^{\circ} \mathrm{C}$ in $1 \%$ uranyl acetate and methanol. After dehydration through an ethanol series, the samples were embedded in Spurr medium containing propylenoxide. Ultrathin sections, cut on a Leica UC7 (Leica, Wetzlar, Germany), were post-stained with uranyl acetate and bismuth oxynitrate and examined using an Hitachi HT-7700 TEM (Hitachi, Tokyo, Japan) at $80 \mathrm{kV}$.

Genomic DNA was extracted using an Axygen DNeasy plant Kit (Axygen Biotechnology, Hangzhou, China) according to the manufacturer's instructions after approximately $15 \mathrm{mg}$ of filaments were added to $1 \mathrm{ml}$ of $0.5 \mathrm{~mm}$ glass beads and 350 $\mu \mathrm{L}$ of phosphate buffer solution (PBS, pH 7.0). The algal cells were lysed by bead beating at $5000 \times \mathrm{g}$ for $2 \mathrm{~min}$ in a minibeadbeater (Model 3110BX, Biospec Products, Bartlesville, OK, USA). The PCR amplifications were performed according to MARIN et al. (2003), where the $18 \mathrm{~S}$ rDNA was amplified using the EAF3 and BR primers. The sequence amplification profile consisted of an initial 5 min denaturing step at $95{ }^{\circ} \mathrm{C}$, 34 cycles of denaturing at $94{ }^{\circ} \mathrm{C}$ for $45 \mathrm{~s}, 30 \mathrm{~s}$ annealing at 55 ${ }^{\circ} \mathrm{C}, 90 \mathrm{~s}$ extension at $72{ }^{\circ} \mathrm{C}$, and a final extension of $10 \mathrm{~min}$ at $72{ }^{\circ} \mathrm{C}$. The primer and amplification procedures of ITS sequence follwed those of HAYAKAWA et al. (2012) and tufA follwed those of FAMÀ et al. (2002). ContigExpress Project (Invitrogen, Grand Island, New York USA) was used to edit low-quality regions and assemble the partial sequences.

Sequences for phylogenetic analyses were downloaded from GenBank (http://www.ncbi.nlm.nih.gov/) based on a BLAST search. Sequences initially aligned using mafft7.2 (KATOH \& STANDLEY 2013) and manually edited and adjusted by using MEGA6 (TAMURA et al. 2013). The ITS1 and ITS2 sequences were manually aligned according to their secondary structure. 18S rDNA and ITS sequence positions that could not be aligned with confidence were removed prior to the analysis. ModelTest3.72 (Posada \& Crandall 1998) was used to select the evolutionary best-fit model according to hierarchical likelihood ratio tests and Akaike information criterion. The best-fit model for tufA was GTR $+\mathrm{I}+\mathrm{G}$. Due to the different substitution

Table 1. Collection information and GenBank accession numbers newly obtained in this study.

\begin{tabular}{|c|c|c|c|c|}
\hline \multirow[t]{2}{*}{ Strain } & \multirow[t]{2}{*}{ Isolator, isolation data } & \multicolumn{3}{|c|}{ GenBank accession numbers } \\
\hline & & 18S rDNA & ITS rDNA & tufA \\
\hline $\begin{array}{l}\text { Lithotrichon fluminensis } \\
\text { FACHB-2334 }\end{array}$ & $\begin{array}{l}\text { B.W. Liu, Guangxi province, China. On the } \\
\text { stones in a stream, freshwater. } \\
\text { December } 2017 \text {. }\end{array}$ & MH374176 & MH371015 & МH356486 \\
\hline
\end{tabular}


rates of the $18 \mathrm{~S}$ rDNA and ITS rDNA markers, we performed analyses on partitioned data sets and calculated evolutionary models separately for $18 \mathrm{~S}$ rDNA, ITS1, 5.8S and ITS2. The models for each partition were as follows: $\mathrm{TrN}+\mathrm{I}+\mathrm{G}$ model for 18S rDNA (1761 bases), GTR + G model for ITS1 (314 bases), TrNef $+\mathrm{I}+\mathrm{G}$ model for $5.8 \mathrm{~S}$ ( 157 bases) and GTR $+\mathrm{G}$ model for ITS2 (268 bases). Phylogenetic trees, using the maximum likelihood (ML) and Bayesian methods, were constructed by RAxML8.0 (Stamatakis 2014) and MrBayes3.1.2 (HuelsenbeCK \& RoNQUisT 2001). Bootstrap analyses with 1000 replicates of the ML dataset were performed to estimate the statistical reliability. Bayesian analyses were performed with $4 \times 10^{6}$ generations of Markov chain Monte Carlo iterations and the trees were sampled every $1 \times 10^{3}$ generations. It was assumed that a stationary distribution was reached when the average standard deviation of the split frequencies between two runs was lower than 0.01 . The first $25 \%$ of the calculated trees was discarded as burn in, and the remaining samples were used to construct a Bayesian consensus tree and to infer posterior probabilities. The bootstrap values and posterior probabilities are presented at the nodes. The resulting phylogenetic trees were edited using Figtree 1.4.2 (http://tree.bio.ed. ac.uk/software/figtree/).

\section{Results}

\section{Morphological observations}

\section{Gongrosira fluminensis Fritsch in FRITSCH (1929)}

Thallus of strain FACHB-2334 without calcification formed cushionlike masses on stones in the fast-flowing stream (Fig. 1). Upright threads grew to approximately the same height $(80-100 \mu \mathrm{m})$ and formed a very compact tuft (Fig. 2); Erect part scarcely branch at all in their lower portions, but towards the tips extensive branching occurs leading to the formation of numerous short branches (Fig. 3). Cells cylindrical, subcylindrical or very slightly barrel-shaped, 5-7 $\mu \mathrm{m}$ wide, length $1-3$ times longer than width. Chloroplast single and parietal, pyrenoid $1-3$, mostly 1 per cell (Fig. 4). The end cells of the branchlets were always somewhat swollen, 4-6 $\mu \mathrm{m}$ in diameter (Fig. 4). There is a great tendency for these enlarged cells to be akinetes detached from the threads (Fig. 5). In the germination of these akinetes, colourless rhizoid-like prolongation is being formed (Fig 6, 7). It possessed a compact creeping basal portion and cells of the basal stratum were in great part more or less rounded, often polygonal in outline, 3-5 $\mu \mathrm{m}$ in diameter (Fig. 8). Adjacent cells were without the plasmodesmata (Fig. 9). Pyrenoid was traversed by a thylakoid membrane (Fig. 10).

\section{Phylogenetic analyses}

For analyses performed in this study, three alignments were generated: (1) the $18 \mathrm{~S}$ rDNA alignment containing 105 taxa with $1761 \mathrm{bp}$ of representatives of the Ulvophyceae, (2) the tufA alignment containing 84 taxa with $822 \mathrm{bp}$ of representatives of the Ulvophyceae, and (3) concatenated dataset of $3018 \mathrm{~S}$ rDNA and ITS rDNA sequences (2500 bp) of the Ulvales. Sequence names retrieved from GenBank had been checked for their current taxonomic name according to ŠKALOUD et al. (2018) Phylogenetic analyses of the 18S rDNA (Fig. 11) and tufA (Fig. 12) sequences were used to determine the unambiguous phylogenetic placement of the the Gongrosira fluminensis Fritsch (FACHB-2334) within the order Ulvales (Ulvophyceae) with a high support value (BP/PP, 100/1.00). Phylogenetic trees of 18 S rDNA showed that the family Kornmanniaceae was clearly split into four lineages representing genera (Pseudendoclonium Wille, Halofilum Darienko et Pröschold, Paulbroadya Darienko et Pröschold, Lithotrichon Darienko et Pröschold) and the Gongrosira fluminensis Fritsch (FACHB-2334) and Dilabifilum sp. (SAG 2038) THÜs formed a robust clade as the most basal branch of the family Kornmanniaceae adjacent to the family Bolbocoleonaceae. In the phylogenetic tree of tufA, Gongrosira fluminensis Fritsch as a separate clade formed a discrete clade with the genus Bolbocoleon Pringsheim (Bolbocoleonaceae). To further resolve the placement of Gongrosira fluminensis Fritsch in the Ulvales, analyses were also conducted using a concatenated data set (18S rDNA+ITS rDNA) (Fig. 13). Results obtained from the concatenated data set showed a similar scenario with that from 18S rDNA that the clade including Gongrosira fluminensis Fritsch (FACHB-2334) and Dilabifilum sp. (SAG 2038) THÜs having the closest relationship with each other (BP/ PP, 100/1.00) was the most basal branch of the family Kornmanniaceae.

\section{Discussion}

Gongrosira fluminensis Fritsch was distinguishable mainly for its unique morphological features of basal stratum, upright threads, akinetes and calcification (FRITSCH 1929; PrINTZ 1964; JoHn 2002; HU \& WeI 2006; JoHN et al. 2011; Maulood et al. 2013; WeHr et al. 2015). Our specimen sampled from Guangxi Province, China, was almost the same as the original description and illustrations of Gongrosira fluminensis Fritsch (FRITSCH 1929; PrinTz 1964). Pseudoparenchymal basal stratum with rounded or polygonal cells grew into dense littlebranched upright threads that reached approximately the same height and formed strong cushions without calcification. The specific akinete formation and germination was another important feature for the identification. What slightly different were the smaller cells and cells of the basal stratum without obvious thick irregularly stratified colourless walls in our speciemen, which might attributed to its out of full development and phenotypic plasticity. This species was very close to G. incrustans (Reinsch) Schmidle and G. scourfieldii West, G.S., but the latter were either encrusted with obvious calcification or all parts richly branched clearly differed from $G$. fluminensis Fritsch.

Examination of the ultrastructural characteristics refused the placement of Gongrosira fluminensis 

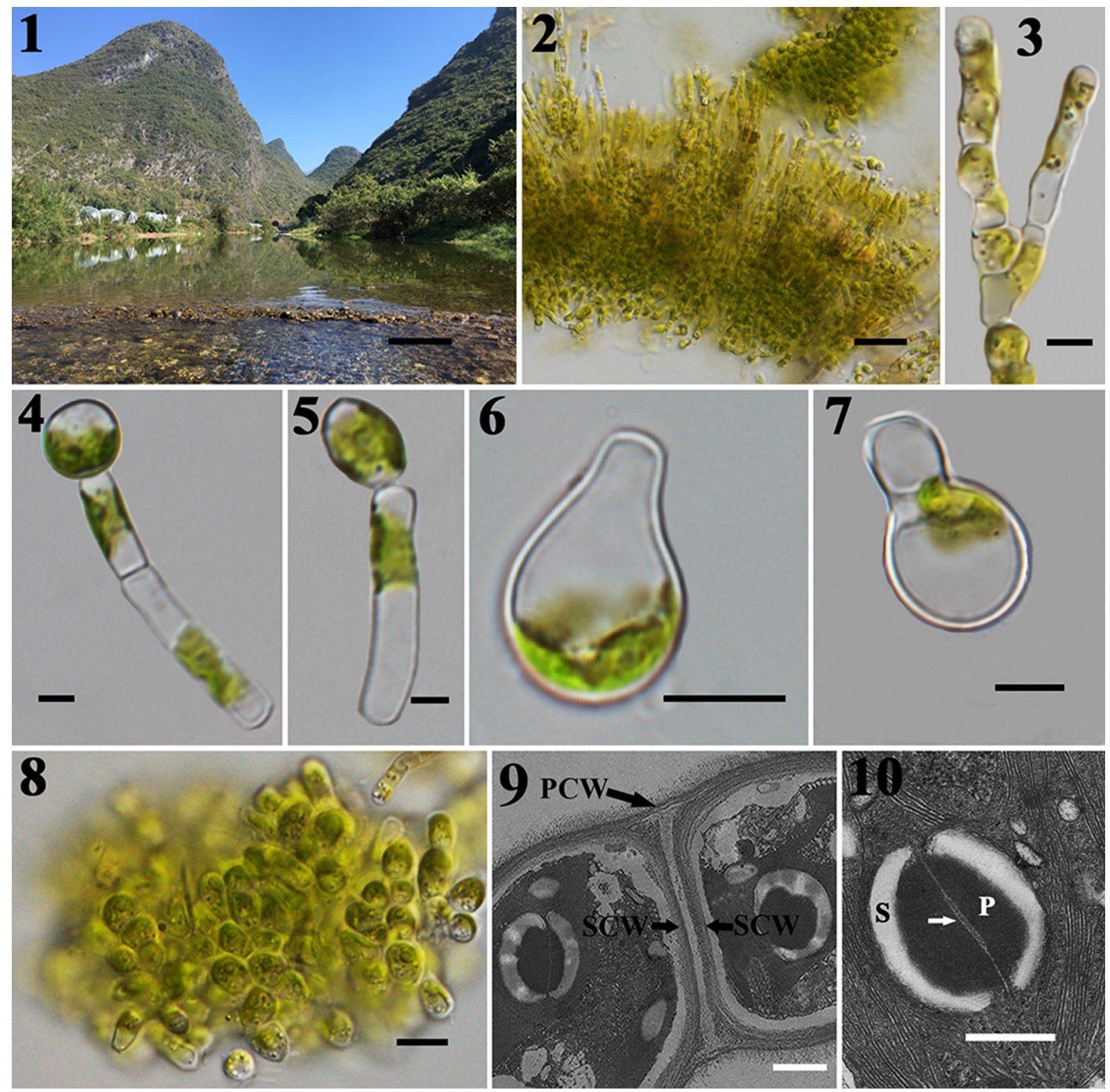

Figs. 1-10. Morphology of Lithotrichon fluminensis FACHB-2334. (1) The natural enviroment of Lithotrichon fluminensis. Scale bar 5 m; (2) Fully developed upright system. Scale bar $20 \mu \mathrm{m}$; (3) Apex of threads showing branching. Scale bar $5 \mu \mathrm{m}$; (4) Apex of one of its branches, showing akinete formation. Scale bar $2 \mu \mathrm{m}$; (5) Akinetes in course of detachment. Scale bar $2 \mu \mathrm{m}$; (6-7) Germinating akinete. Scale bar 10 $\mu \mathrm{m}$; (8) Parts of the basal statum. Scale bar $5 \mu \mathrm{m}$; (9) Ultrastructure of cell wall. Scale bar $1 \mu \mathrm{m}$; (10) Pyrenoid with a traversing thylakoid membrane. Scale bar $500 \mathrm{~nm}$. P, pyrenoid; S, starch envelope; PCW, primary cell wall; SCW, secondary cell wall.

Fritsch into Chaetophorales. Cells in Chaetophorales kept interconnected by plasmodesmata (STEWART et al. 1973; John 1984; MelKonian 1990), while Gongrosira fluminensis Fritsch was without the plasmodesmata which confirmed that Gongrosira fluminensis Fritsch should be excluded from the Chaetophorales. Pyrenoid structures of Gongrosira fluminensis Fritsch was also different from that of Chaetophorales (STEWART et al. 1973).

Traditionally, most freshwater and terrestrial green algae belonged to the classes Chlorophyceae and Trebouxiophyceae (ETTL \& GÄRTNER 1995). However, phylogenetic analyses of green algae using 18 rDNA sequences had shown that many filamentous and sarcinoid algae previously assigned to the Chlorophyceae or Trebouxiophyceae are members of the Ulvophyceae (DARIENKo \& PRÖSChOLd 2017).

Here we provided the first molecular record of the genus Gongrosira Kützing. Molecular data including 18S rDNA and the chloroplast encoded tufA with strong support showed that Gongrosira fluminensis Fritsch is a member of the Ulvales (Ulvophyceae) instead of Chaetophorales (Chlorophyceae). Further study of concatenated data set of $18 \mathrm{~S}$ rDNA and ITS rDNA revealed that Gongrosira fluminensis Fritsch was the new member of the genus Lithotrichon Darienko et Pröschold within family Kornmanniaceae. The limited DNA sequences of tufA and ITS rDNA might account for the differences between each analysis. Within the genus Lithotrichon 


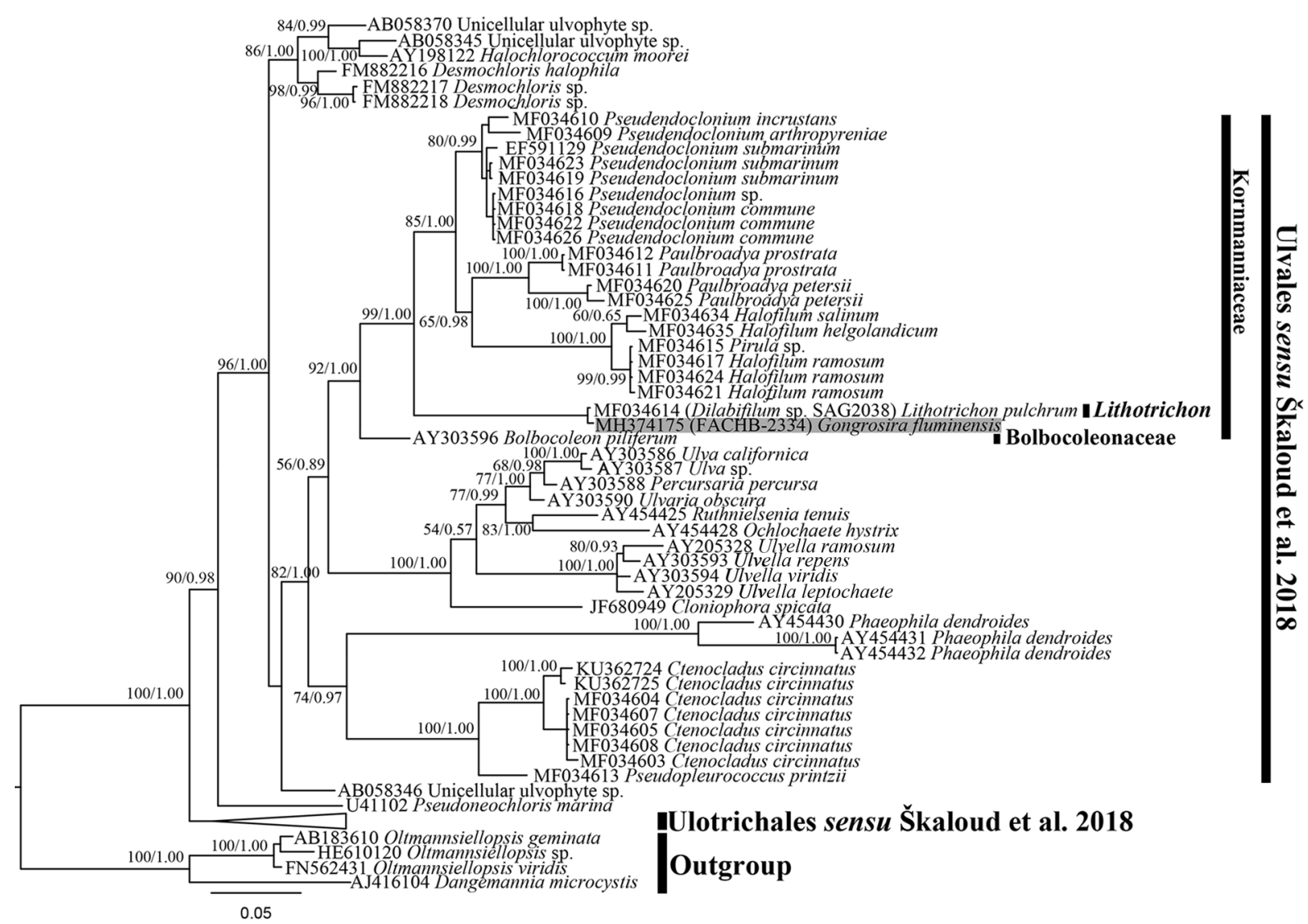

Fig. 11. Phylogenetic tree of the Ulvophyceae constructed by the $18 \mathrm{~S}$ rDNA sequences. The numbers above on the nodes represent the Bayesian inference posterior probabilities (PP) and bootstrap support values (BP) from maximum likelihood (ML, constructed by RAxML). Values above 0.5 for $\mathrm{BI}$ and 50 for ML are shown. The new sequence of this study is shaded in grey.

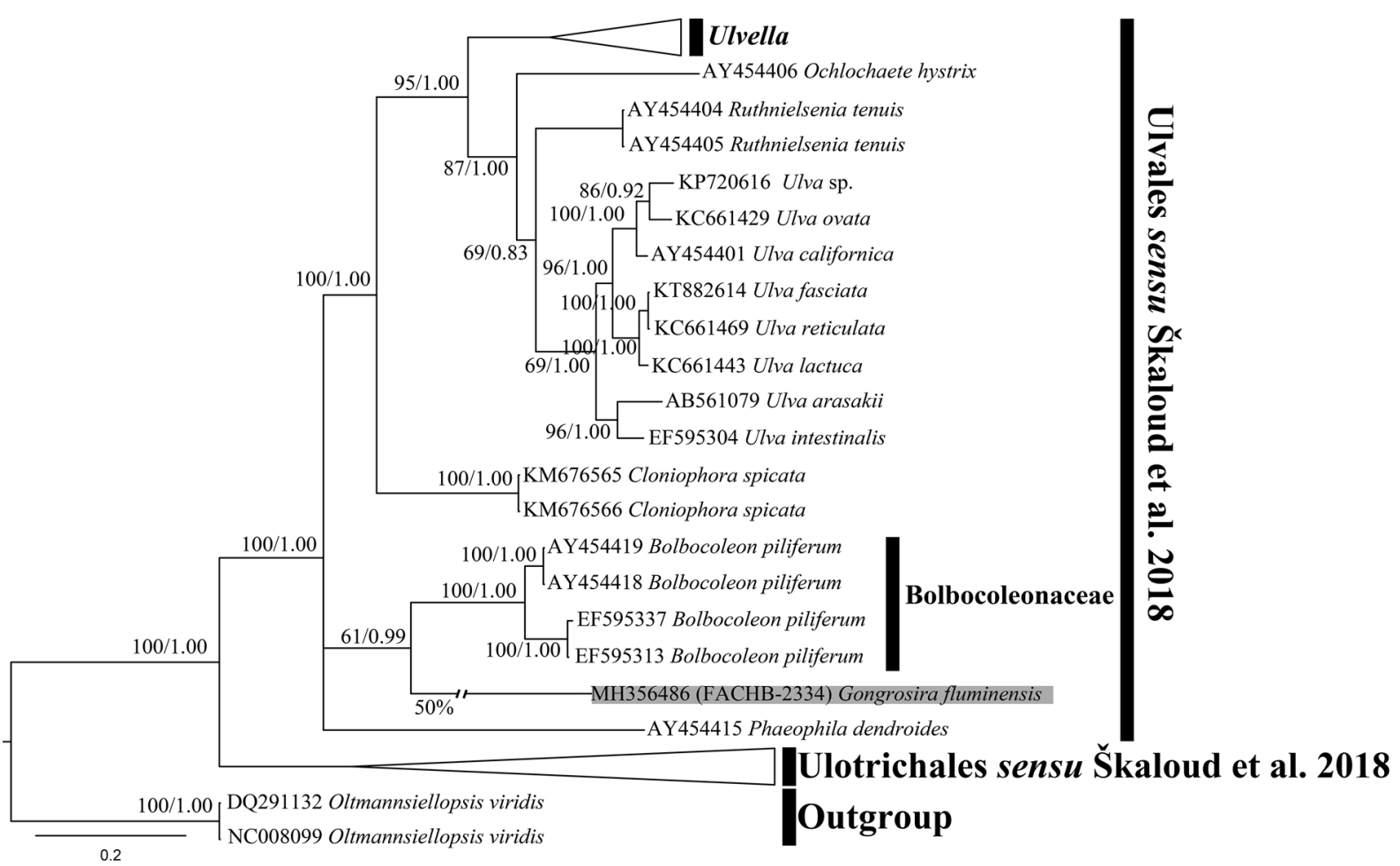

Fig. 12. Phylogenetic tree of the Ulvophyceae constructed by the tufA sequences. The numbers above on the nodes represent the Bayesian inference posterior probabilities (PP) and bootstrap support values (BP) from maximum likelihood (ML, constructed by RAxML). Values above 0.5 for BI and 50 for ML are shown. The new sequence of this study is shaded in grey. 


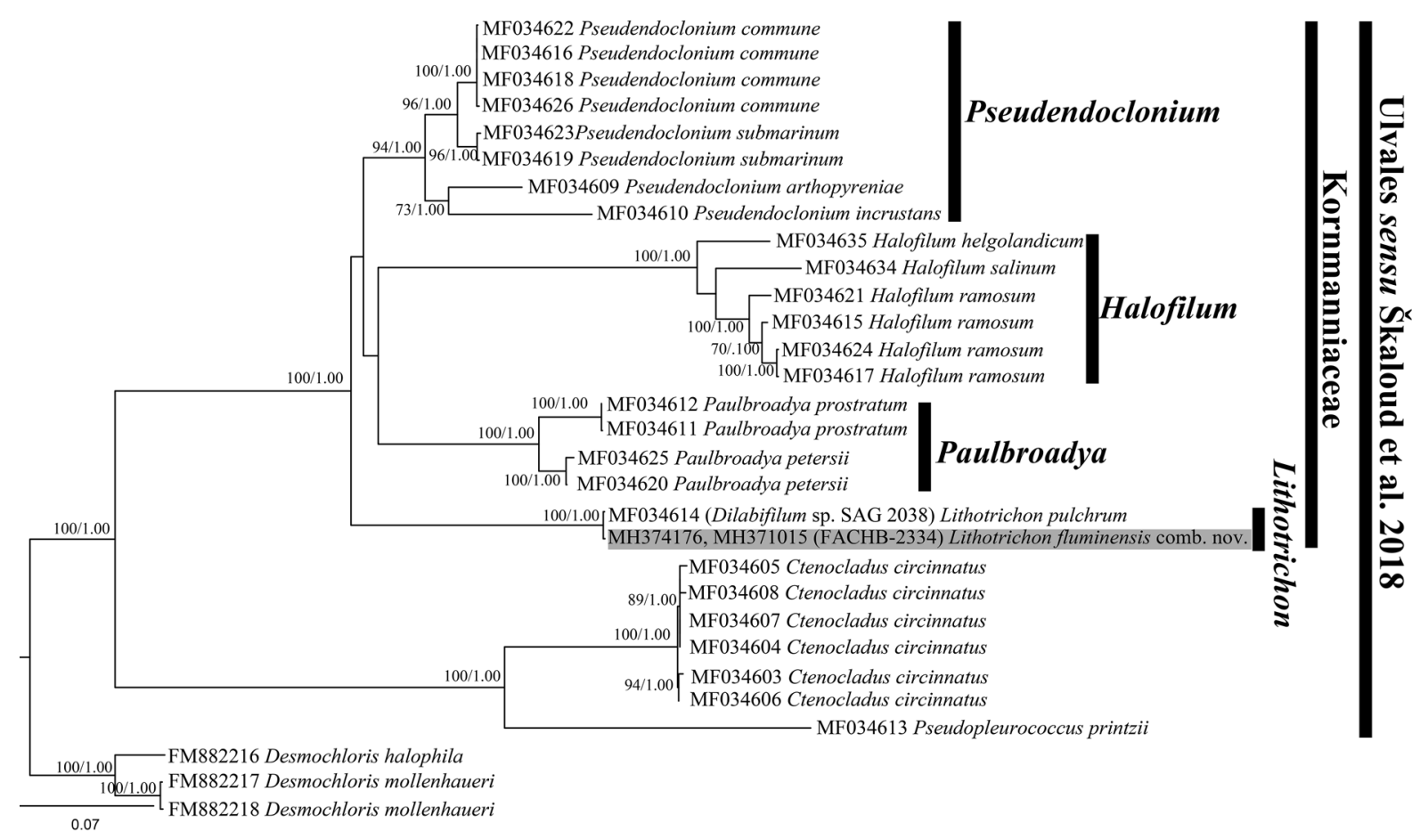

Fig. 13. Phylogenetic tree of the Ulvophyceae constructed by the concatenated data set of $18 \mathrm{~S}$ rDNA and ITS rDNA sequences. The numbers above on the nodes represent the Bayesian inference posterior probabilities (PP) and bootstrap support values (BP) from maximum likelihood (ML, constructed by RAxML). Values above 0.5 for BI and 50 for ML are shown. The new sequence of this study is shaded in grey.

DARIENKo et Pröschold, Dilabifilum sp. (SAG 2038) Thüs and Gongrosira fluminensis Fritsch (FACHB-2334) had the almost identical 18S rDNA and ITS rDNA sequences (just two different bases in 18S rDNA and one in ITS rDNA) which was initially unexpected. It should be noted that the morphology of Gongrosira fluminensis Fritsch (FACHB-2334) corresponded to its description in the literature and occurred in the same habitat (running water bodies like small rivers) with Dilabifilum sp. (SAG 2038) Thüs. Dilabifilum sp. (SAG 2038) Thüs was originally described as the photobiont of the lichen Verrucaria rheitrophila submerged approx. 10 $\mathrm{cm}$ below the water surface on siliceous rock in a river by THüs et al. (2011).

Our study clearly showed that the Gongrosira fluminensis Fritsch should be classified in Ulvales as a new member of genus Lithotrichon Darienko et Pröschold instead of Chaetophorales. Therefore, we transferred the Gongrosira fluminensis Fritsch from Chaetophorales (Chlorophyceae) to Ulvales (Ulvophyceae) as the new combination species of Lithotrichon Darienko et Pröschold - Lithotrichon fluminensis (Fritsch) Liu et al. comb. nov. We refrained from making any conclusions whether Gongrosira fluminensis Fritsch (FACHB-2334) was synonym of Dilabifilum sp. (SAG 2038) Thüs primarily because of insufficient specimens and collection information.

Gongrosira fluminensis Fritsch is not the type species of the genus Gongrosira Kützing, which means that the real phylogenetic position of the genus Gongrosira Kützing is still unknown, but the obvious phylogenetic position of Gongrosira fluminensis Fritsch in the genus Lithotrichon Darienko et Pröschold (Ulvales, Ulvophyceae ) may contribute to solving the taxonomic problems of the genus Gongrosira Kützing.

In the future, more specimens in conjunction with natural morphological investigation and molecular analyses are required to reevaluate the microfilamentous genus Gongrosira and reveal hidden diversities among the Ulvophyceae which certainly will renovate our cognition of Ulvophyceae.

\section{Taxonomic treatment}

Lithotrichon fluminensis (Fritsch) B.W. Liu, Q.H. Wang, S.Y. Li, J. Fang, G.X. Liu et Z.Y. Hu comb. nov. (Figs 1 - 10)

Basionym: Gongrosira fluminensis Fritsch in FRITSCH (1929)

Description: Thallus forming cushionlike masses on stones in the fast-flowing stream, possesses a compact creeping basal portion attached to the rock surface and producing from practically every cell an upright thread, the latter in their entirety growing to approximately the same height and forming a very compact tuft. Over considerable stretches the cells may be so closely fitted together as to form a compact pseudoparenchyma. Erect part scarcely branch at all in their lower portions, but towards the tips extensive branching occurs leading to the formation of numerous short branches. There is no calcification either of the creeping system or of the upright portion. 
Reference strains: Cultured strain FACHB-2334 was deposited in the Freshwater Algae Culture Collection at the Institute of Hydrobiology (FACHB collection) (http://algae.ihb.ac.cn). Formaldehyde-fixed material was stored at the Freshwater Algal Herbarium, Institute of Hydrobiology, Chinese Academy of Science, Wuhan, China, as specimen No. GXGL201704.

\section{ACKNOWLeDGeMents}

This research was funded by the National Natural Science Foundation of China (Grant No. 31770220 and No. 31670202). Special thanks also go to anonymous reviewers for their editorial corrections and comments leading to improve the manuscript.

\section{REFERENCES}

Bischoff, H.W. \& Bold, H.C. (1963): Phycological studies IV. Some soil algae from enchanted rock and related algal species. - 95 pp., University of Texas Publication, Texas.

Borzi, A. (1883): Saggio di ricerche Sulla biologia delle alghe. Ctenocladus, gen. nov. - Studi Algologici 1: 27-50.

Bourrelly, P. (1972): Les Algues d'eau Douce: Les Algues Vertes N. Boubée \& Cie. - 281 pp., Paris.

CAmbra SÁnchez, J.; Álvarez Cobelas, M. \& Aboal Sanjurjo, M. (1998): Lista florística y bibliográfica de los clorófitos (Chlorophyta) de la Península Ibérica, Islas Baleares e Islas Canarias. - 614 pp., Asociación Española de Limnología, Burgos.

DARIENKo, T. \& PröSChOLD, T. (2017): Toward a monograph of non-marine Ulvophyceae using an integrative approach (Molecular phylogeny and systematics of terrestrial Ulvophyceae II.). - Phytotaxa 324: 001-041.

EtTL H. \& GäRTNer G. (1995): Syllabus der Boden-, Luftund Flechtenalgen. - 721 pp., Stuttgart, Jena and Heidelberg, Gustav Fischer.

Famà, P.; Wysor, B.; Kooistra, W.H.C.F. \& Zuccarello, G.C. (2002): Molecular phylogeny of the genus Caulerpa (Caulerpales, Chlorophyta) inferred from chloroplast tufA gene. - Journal of Phycology 38: 1040-1050.

FRITSCH, F.E. (1929): The encrusting algal communities of certain fast-flowing streams. - New Phytologist 28: $188-190$

FRITSCH, F.E. (1935): The Structure and Reproduction of the Algae, Vol. I. - 721 pp., Cambridge University Press, Cambridge.

Guiry, M.D. \& Guiry, G.M. (2018): AlgaeBase. World-wide electronic publication, National University of Ireland, Galway. http://www.algaebase.org; searched on 19 May 2018.

Hayakawa, Y.; Ogawa, T.; Yoshikawa, S.; OHKi, K. \& Kamiya, M. (2012): Genetic and ecophysiological diversity of Cladophora (Cladophorales, Ulvophyceae) in various salinity regimes. - Phycological Research 60: 86-97.

Hu, H.G. \& WeI, Y.X. (2006): Chinese Freshwater Algae: System, Classification and Ecology. - 1023 pp., Science Press, Beijing.

HUELSENBECK, J.P. \& RONQUIST, F. (2001): MRBAYES: Bayesian inference of phylogenetic trees. - Bioinformatics 17 : $754-755$

JoHN, D.M. (1984): On the systematic of the Chaetophorales. - In: Irvine, D.E.G. \& JoHN, D.M. (eds): Systematics of the Green Algae. - pp. 207-232, Academic Press,
London.

JoHn, D.M. (2002): Orders Chaetophorales, Klebshormidiales, Microsporales, Ulotrichales. - In: John, D.M.; WhitTon, B.A. \& BrooK, A.J. (eds): The Freshwater Algal Flora of the British Isles. An identification guide to freshwater and terrestrial algae. - pp. 433-468, Cambridge University Press, New York.

John, D.M.; Whitton, B.A. \& BRook A.J. (2011): The freshwater algal flora of the British Isles. An identification guide to freshwater and terrestrial algae. Second edition. - 878 pp., Cambridge University Press, Cambridge.

JoHNSON, L.R. \& JoHN, D.M. (1992): Taxonomic observations on some uncommon and new Gongrosira species (Chaetophorales sensu stricto, division Chlorophyta), - British Phycological Journal 27: 153-163.

KatoH, K. \& Standley, D.M. (2013): MAFFT Multiple Sequence Alignment Software Version 7: Improvements in Performance and Usability. - Molecular Biology and Evolution 30: 772-780.

KützING, F.T. (1843): Phycologia Generalis Oder Anatomie, Physiologie und Systemkunde der Tange. -458 pp., Leipzig, Germany.

KüTZING, F.T. (1883): Beitrage zur kenntnis ueber die Entstehung und Metamorphose der niedern vegetabilischen Organissem. - Linnaea 8: 335-384.

Liv, B.W.; LiU, X.D.; Hu, Z.Y.; ZhU, H. \& LiU G.X. (2016): Phylogenetic position and morphological observation of the Ctenocladus circinnatus Borzi, a rare green alga from Changtang Plateau, China. - Phytotaxa 260: 75-82.

Marin, B.; Palm, A.; KlingberG, M. \& Melkonian, M. (2003): Phylogeny and taxonomic revision of plastid-containing euglenophytes based on SSU rDNA sequence comparisons and synapomorphic signatures in the SSU rRNA secondary structure. - Protist 154: 99-145.

Maulood, B.K.; Hassan, F.M.; Al-Lami, A.A.; Toma, J.J. \& IsmAIL, A.M. (2013): Checklist of algal flora in Iraq. - 94 pp., Ministry of Environment, Baghdad.

Melkonian, M. (1990): Phylum Chlorophyta: Class Chlorophyceae. - In: Margulis, L.; Corliss, J.O.; Melkonian, M. \& Chapman, D. (eds): Handbook of Protoctista. - pp. 608-616, Jones \& Bartlett Publishers, Boston.

Nielsen, R.; Petersen, G.; Seberg, O.; Daugbjerg, N.; O'Kelly, C.J. \& Wysor, B. (2013): Revision of the genus Ulvella (Ulvellaceae, Ulvophyceae) based on morphology and tufA gene sequences of species in culture, with Acrochaete and Pringsheimiella placed in synonymy. - Phycologia 52: 37-56.

O’Kelly, C.J.; Wysor, B. \& Bellows, W.K. (2004): Gene sequence diversity and the phylogenetic position of algae assigned to the genera Phaeophila and Ochlochaete (Ulvophyceae, Chlorophyta). - Journal of Phycology 40: 789-799.

Posada, D. \& Crandall, K.A. (1998): Modeltest: Testing the model of DNA substitution. - Bioinformatics 14: $817-818$

PrinTZ, H. (1964): Die Chaetophoralen der Binnengewässer (eine systematische Übersicht). - Hydrobiologia 24: $1-376$.

REINSCH, P.F. (1867): Die algenflora des mittleren Theil von Franken. -238 pp., Nurnberg.

SchmidLe, W. (1901): Über drei Algengenera. - Berichte der deutschen botanischen Gessellschaft 19: 10-24.

SiLVA, P. C. (1952): A review of nomenclatural conservation inthe algae from the point of view of the type method. - Univ.Calif. Publ. Bot. 25: 241-323. 
ŠKaloud, P.; Nedbalová, L.; Elster, J. \& KomÁreK, J. (2013): A curious occurrence of Hazenia broadyi spec. nova in Antarctica and the review of the genus Hazenia (Ulotrichales, Chlorophyceae). - Polar Biology 36: 1281-1291.

ŠKaloud, P.; Rindi, F.; Boedeker, C. \& Leliaert, F. (2018): Freshwater Flora of Central Europe. Volume 13, Chlorophyta: Ulvophyceae. - 288 pp., Springer Spektrum, Berlin, Heidelberg.

Smith, G.M. (1950): The Fresh Water Algae of the United States, 2nd Ed. McGraw-Hill, New York.

Stamatakis, A. (2014): RAxML version 8: a tool for phylogenetic analysis and post-analysis of large phylogenies. - Bioinformatics 30: 1312-1313.

Stewart, K.D.; Mattox, K.R. \& Floyd, G.L. (1973): Mitosis, cytokinesis, the distribution of plasmodesmata, and other cytological characteristics in the Ulotrichales, Ulvales, and Chaetophorales: phylogenetic and taxonomic considerations. - Journal of Phycology 9: 128-141.

Tamura, K.; Stecher, G.; Peterson, D.; Filipski, A. \& KumAR, S. (2013): MEGA6: Molecular Evolutionary Genetics Analysis version 6.0. - Molecular Biology and Evolution 30: 2725-2729.

TÄUSCHER, L. (2016): Algen (Cyanobacteria et Phycophyta). - In: Frank, D. \& SChNitTer, P. (eds): Pflanzen und Tiere in
Sachsen-Anhalt Ein Kompendium der Biodiversität. pp. 63-112, Westermann Druck Zwickau, Rangsdorf. Thüs, H.; Muggia, L.; PéreZ-Ortega, S.; Favero-Longo, S.E.; Joneson, S.; O’Brien, H.; Nelsen, M.P.; DuqueThüs, R.; Grube, M.; FriedL, T.; Brodie, J.; ANDrew, C.J.; LÜCKING, R.; Lutzoni, F. \& GuEIDAN, C. (2011): Revisiting photobiont diversity in the lichen family Verrucariaceae (Ascomycota). - European Journal of Phycology 46: 399-415.

TuPA, D.D. (1974): An investigation of certain Chaetophoralean algae. - Nova Hedwigia 46: 1-155.

Watanabe, S.; Chappell, D.F. \& Floyd, G.L. (1992): Ultrastructure of the flagellar apparatus of the gametes of Gongrosira papuasica (Chlorophyta). - British Phycological Journal 27: 21-28.

Wehr, J.D.; Sheath, R.G. \& Patrick Kociolek, J. (2015): Freshwater algae of North America: Ecology and Classification. - 1050 pp., Elsevier, London.

WeSt, G.S. (1918): A new species of Gongrosira. - Journal of the Royal Microscopical Society 38: 30-31.

(C) Czech Phycological Society (2019)

Received October 2, 2018

Accepted November 27, 2018 